\title{
URGENSI DITERAPKANNYA PRINSIP GOOD CORPORATE GOVERNANCE PADA PENGELOLAAN PERUSAHAAN DAERAH
}

\author{
Maria Fransiska Owa da Santo \\ Fakultas Hukum Unika Widya MAndira Kupang \\ Jl. A. Yani 50-52, Kupang 850001 \\ Email: sisca_dasanto@yahoo.com
}

\begin{abstract}
The company has an important role in generating revenue for the region. A local company as befits the company is generally established with the aim to make a profit. Like a company, the company may suffer losses. This loss can be caused by the bad of organizer by the company because the company organs done without regard to principles of good corporate governance. A region enterprise of Flobamor is the one of local company owned by NTT provincial government. In practice in the field proves that although PD Flobamor has changed legal status to PT Flobamor its inception has not been able to contribute positively to the increase in revenue (PAD).
\end{abstract}

Keywords: The Company; The Principles of Good Corporate Governance.

\begin{abstract}
Abstrak
Perusahaan daerah memiliki peranan yang penting dalam menghasilkan pendapatan bagi daerah. Layaknya sebuah perusahaan, perusahaan daerah dapat mengalami kerugian. Kerugian ini dapat disebabkan oleh buruknya pengelolaan perusahaan daerah karena dilakukan tanpa memperhatikan prinsip-prinsip Good Corporate Governance (GCG). Fokus kajian dalam tulisan ini adalah (1)Peranan organ perusahaan daerah dalam menjalankan kegiatan perusahaan; dan (2) Pentingnya Prinsip GCG dalam pengelolaan perusahaan daerah.Perusahaan Daerah Flobamor merupakan salah satu perusahaan daerah (BUMD/Badan Usaha Milik Daerah) di Provinsi NTT. Dalam praktek dilapangan membuktikan bahwa PD Flobamor belum mengalami keuntungan. Walaupun telah berubah status bentuk badan hukum dari PD menjadi PT BUMD namun belum mampu berkontribusi secara positifterhadap peningkatan Pendapan Asli Daerah (PAD).
\end{abstract}

Kata Kunci : Perusahaan Daerah; Prinsip Tata Kelola Perusahaan yang Baik.

\section{A. Pendahuluan}

Hukum merupakan cermin yang memantulkan kepentingan masyarakat. Karena kepentingan masyarakat selalu berubah, maka secara operasional hukum juga dituntut untuk selalu mengubah dirinya. Apabila dilihat secara sosiologis perangkat aturan hukum telah menjelmakan dirinya menjadi responsive law brarti yang termaju dalam fase perkembangan hukum karena hukum berkembang dari represissve law menjadi autonomous law dan kemudian berbentuk responsive law, ${ }^{1}$ bahkan saat ini hukum yang sedang dikembangkan kearah hukum yang progresif atau progresive law. Dalam merespons kepentingan masyarakat, hukum tidak selalu menyediakan perangkatnya persis seperti apa yang terjadi dalam masyarakat bahkan lebih dari itu hukum harus juga memberi bentuk kepada masyarakat, yakni menyediakan platform kearah tujuan pembangunan masyarakat itu sendiri. Dalam konteks ini, hukum dikenal dengan istilah "tool of social engineering"?

1. Bernad L Tanya, Simanjuntak, Yoan N, Hage, Markus Y, 2006, Teori Hukum, Strategi Tertib Manusia Lintas Ruang dan Generasi, Surabaya, CV Kita, hlm 70.

2. Munir Fuady, 1994, "Potret Hukum Bisnis Kita Dewasa Ini", Surat kabar Bisnis Indonesia, 15 Oktober 1993, dalam : Hukum Bisnis Dalam Teori dan Praktek Bagian Kesatu, Bandung, Citra Aditya Bakti, , hlm. 1. 
Dalam dunia hukum bisnis, tensi terhadap perubahan hukum cukup tinggi, karena bisnis sendiri berkembang begitu cepat sedangkan hukum bisnis (perangkat peraturannya) seringkali tertinggal. ${ }^{3}$

Kebijakan pemberian otonomi daerah dan desentralisasi yang luas, nyata, dan bertanggung jawab kepada daerah merupakan langkah strategis. Menurut Bagir Manan, otonomi luas bisa bertolak dari prinsip semua urusan pemerintahan pada dasarnya menjadi urusan rumah tangga daerah, kecuali yang ditentukan sebagai urusan pusat.Dalam negara moderen, lebih-lebih apabila dikaitkan dengan paham negara kesejahteraan, urusan pemerintahan tidak dapat dikenali jumlahnya. ${ }^{4}$ Secara khusus otonomi daerah menginginkan daerah memiliki kemampuan dalam menggali dan mengembangkan sumber daya yang dimiliki sehingga derajat kapasitas fiskalnya mampu memenuhi tuntutan pembiayaan pembangunan di daerahnya. Salah satu komponen terpenting sumber pembiayaan pembangunan daerah adalah Pendapatan Asli Daerah (selanjutnya disingkat PAD). Komponen inilah harus dikelola secara lebih efisien dan efektif agar semakin kuat peranannya dalam memperkecil ketergantungan pemerintah daerah pada pemerintah pusat di bidang pembiayaan pembangunan. ${ }^{5}$

Dalam upaya penguatan penerimaan daerah yang bersumber dari kekayaan daerah yang dipisahkan, maka peranan investasi Pemerintah melalui Badan Usaha Milik Daerah (selanjutnya disingkat BUMD) sangat diharapkan, selain sebagai sumber PAD, BUMD diharapkan juga sebagai pemacu utama pertumbuhan dan pembangunan ekonomi daerah (engine of growth), sehingga mampu menimbulkan efek multiplier yang besar.

Sebagaimana sebuah perusahaan, perusahaan daerah dapat mengalami kerugian. Kerugian ini dapat disebabkan oleh buruknya pengelolaan perusahaan daerah karena dilakukan tanpa memperhatikan prinsip-prinsip GCG. Selain itu kerugian juga dapat disebabkan karena tidak berfungsinya sistem perencanaan dan pengendalian internal. $^{6}$

Berdasarkan Pasal 157 Undang-Undang Nomor 32 Tahun 2004 tentang Pemerintahan Daerah dan Pasal 6 ayat (1) Undang-Undang Nomor 33 Tahun 2004 tentang Perimbangan Keuangan Antara Pemerintah Pusat dan Pemerintahan Daerah, penerimaan daerah yang berasal dari PAD adalah : Hasil pajak daerah; Hasil retribusi daerah; Hasil pengelolaan kekayaan daerah yang dipisahkan; dan Lain-lain PAD yang sah. Namun dalam perkembangannya di antara semua komponen PAD, yaitu hasil pajak daerah, hasil retribusi daerah dan lain-lain PAD yang syah merupakan penyumbang PAD terbesar, sedangkan hasil pengelolaan kekayaan daerah yang dipisahkan masih sangat kecil peranannya dalam kontribusi PAD. Hal ini menunjukan bahwa investasi Pemerintah yang salah satunya adalah perusahaan daerah belum produktif, karena belum mampu memberikan sumbangan yang signifikan terhadap PAD. ${ }^{7}$

Penulisan ini dilakukan berdasarkan pertimbangan-pertimbangan di atas dan dalam rangka peningkatan peran Perusahaan Daerah agar pengelolaannya lebih efisien dan professional serta memiliki kemampuan lebih, dalam mengakses dana-dana pembiayaan dengan memperhatikan prinsipprinsip Good Corporate Governance (selanjutnya disingkat GCG). Permasalahan yang akan di bahas adalah : (1) Peranan organ perusahaan daerah dalam menjalankan kegiatan perusahaan; dan (2) Pentingnya Prinsip GCG dalam pengelolaan perusahaan daerah.

\section{Ibid.}

4. Muhammad Pazri, "Implementasi Prinsip Good Governance Dalam Sistem Pengelolaan Keuangan Daerah di Indonesia” Badamai Law Journal, Vol. 1, Issues 2, September 2016 , hlm 261.

5. "Media Informasi Otonomi Daerah Indonesia; Tujuan Otonomi Daerah", tersedia di website http://otonomidaerah.com/tujuan-otonomi-daerah/, diakses pada tanggal 06 April 2014.

6. Turiman Fachturahman Nur, 2009, “Terobosan Hukum Memajukan Badan Usaha Milik Daerah (BUMD) Dala Era Otonomi Daerah, Rajawali Garuda Pancasila", tersedia di website http://Rajawaligarudapancasila.blogspot.com/201 1/04/Terobosan-hukum-memajukan-badan-usaha.Html, diakses 7. pada tanggal 26 April 2014.

7. Ibid. 


\section{B. Pembahasan}

\section{Belajar dari Keadaan Perusahaan Daerah Flobamor NTT}

Perusahaan Daerah (selanjutnya disingkat PD) Flobamor yang didirikan berdasarkan Peraturan Daerah Provinsi Nusa Tenggara Timur Nomor 12 Tahun 2008 tentang Pendirian Perusahaan Daerah Flobamor, yang telah beralih status bentuk hukum menjadi PT Flobamor dengan Perda Nomor 13 tahun 2009 tentang Perubahan Bentuk Badan Hukum Perusahaan Daerah (PD) Flobamor menjadi Perseroan Terbatas (PT), adalah salah satu BUMD milik Pemerintah Provinsi Nusa Tenggara Timur.

Upaya dan kebijakan untuk pemberdayaan BUMD ini telah banyak dilakukan, namun karena berbagai masalah, upaya dan kebijakan yang dilaksanakan belum memperoleh hasil sesuai harapan, hal ini tampak yaitu masih rendahnya kontribusi dan sumbangan terhadap PAD, bahkan sejak tahun 2008 usaha PD Flobamor cenderung merugi. Hasil penelusuran pansus DPRD NTT, ${ }^{8}$ sejak tahun 1987 sampai tahun 2008, penyertaan modal pemerintah provinsi telah mencapai Rp. 12,995 miliar sedangkan kontribusi yang diberikan PD Flobamor terhadap pendapatan asli daerah (PAD) hanya Rp. 1,4 miliar lebih bahkan sampai dengan per-bulan Desember 2013, hasil audit Badan Pemeriksa Keuangan (BPK) RI Perwakilan NTT ada temuan bahwa neraca keuangan PT Flobamor merah. Harapan pemerintah daerah dengan merubah status bentuk badan hukum PD menjadi PT Flobamorpun tidak berdampak pada peningkatan kinerja perusahaan yang dalam menjalankan perusahaan tidak memperhatikan Prinsip Good Corporate Governance.

\section{Peranan Organ Perusahaan dalam D a l a m K e r a n g k H u k u m Perusahaan Daerah}

Menurut Westra,${ }^{10}$ Perusahaan Daerah dewasa ini memiliki kedudukan, peran dan fungsi strategis sebagai sumber keuangan daerah namun belum mampu memberikan kontribusi yang optimal dalam meningkatkan pendapatan asli daerah. Perusahaan Daerah dalam kedudukannya sebagai sumber keuangan daerah belum dapat menjalankan fungsi ekonominya secara optimal, dikarenakan perusahaan daerah masih bersifat dwi fungsi (public service dan profit oriented), belum dikelola secara profesional dan bentuk usaha perusahaan daerah tidak sesuai dengan tuntutan penyelenggaraan otonomi daerah.

Mengingat Perusahaan Daerah berada pada dua ranah hukum yaitu hukum publik dan hukum privat, maka kewenangan dan tanggung jawab berkaitan dengan perusahaan daerah meliputi: Ranah hukum publik pemerintah daerah memiliki kewenangan dan tanggung jawab terhadap segala kegiatan, penguasaan dan pengurusan perusahaan daerah, sepanjang berkaitan dengan pembentukan, kepemilikan modal, dan pengawasan perusahaan daerah. Sedangkan Ranah hukum privat direksi selaku organ perusahaan memiliki kewenangan dan tanggung jawab penuh dalam menjalankan kegiatan operasional perusahaan daerah dalam hal berinteraksi dengan pihak ketiga seperti mengadakan perjanjian, mewakili perusahaan baik di dalam maupun di luar pengadilan. ${ }^{11}$

Secara konseptual, BUMD didirikan atas dasar dualisme fungsi dan peranan, yang keduanya sangat sulit, jika tidak dapat dikatakan mustahil, untuk dipadukan. Seperti BUMN, ia punya tugas dalam mengembangkan perekonomian daerah melalui peranannya sebagai institusi public service. Namun pada saat yang sama, BUMD juga diharapkan mampu menghasilkan laba dari usahanya selaku pelayan masyarakat. Secara implisit, BUMD dijadikan sumber dana APBD. Dalam ketentuan, BUMD diwajibkan menyetorkan bagian labanya

\footnotetext{
8 “PD Flobamor, Ibarat Membuang Garam Ke laut", Pos Kupang, edisi 21 Oktober 2008, hlm 1, tersedia di website http://www.pos-kupang.com, diakses pada tanggal 11 Januari 2010.

9. "Neraca Keuangan PT Flobamor Merah (Tak Boleh Ada Penyertaan Modal Pemerintah)", Pos Kupang, edisi 19 Desember 2013, hlm 1, tersedia di website http://www.pos-kupang.com, diakses pada tanggal 20 Desember 2013.

10.I Ketut Westra, 2012, "Kedudukan Hukum Perusahaan Daerah Sebagai Badan Usaha Milik Daerah untuk Meningkatkan Pendapatan Asli Daerah", Disertasi, tersedia di website http://prasetya.ub.ac.id/berita/disertasi-IKetut-Westra, diakses pada tanggal 06 Mei 2014. 
sebagai dana pembangunan daerah sebesar $55 \%$ dari laba bersih tahunan. Dalam tataran operasionalnya, peran dan fungsi ini dilaksanakan secara distortif. Fungsi service lama-kelamaan bergeser sebagai fungsi ekploitatif. $^{12}$

Pada tataran ini, peranan organ perusahaan sangat penting dalam pengelolaan perusahaan, organ yang dimaksud tersebut adalah :

a. Pemegang Saham Perusahaan dan RUPS

Ciri utama dari PT yaitu merupakan subjek hukum yang berstatus badan hukum dengan tanggung jawab terbatas para pemegang saham. Prinsip tanggung jawab terbatas ini diatur dalam pasal 3 ayat (1) UU No. 40 Tahun 2007. Ciri perseroan yaitu pemegang saham hanya bertanggung jawab sebesar setoran atau seluruh saham yang dimilikinya dan tidak meliputi harta kekayaan pribadinya. $^{13}$

Secara yuridis penyertaan modal daerah yang disertakan kedalam perseroan bukan lagi menjadi bagian dari kekayaan daerah tetapi menjdi kekayan perseroan selaku badan hukum yang mandiri (persona standi in judicio). ${ }^{14}$ Seharusnya Kerugian $\mathrm{PT}$ bukan merupakan kerugian daerah. Kedudukan pemerintah dalam PT tidak dapat dikatakan sebagai mewakili daerah sebagai badan hukum publik. Kekayaan daerah yang dipisahkan yang dijadikan penyertaan modal daerah pada PT BUMD ketika disetorkan, maka pada saat itu juga menjadi modal PT BUMD dan bukan lagi menjadi bagian dari kekayaan derah, daerah dalam hal ini adalah sebagai pemegang saham. ${ }^{15}$

b. Direksi Perusahaan

Direksi PT menurut ketentuan Pasal 1 butir 4 UUPT adalah organ perseroan yang bertanggung jawab penuh atas pengurusan perseroan untuk kepentingan dan tujuan perseroan serta mewakili perseroan baik di dalam maupun di luar pengadilan.

c. Komisaris Perusahaan

Dewan komisaris adalah organ yang bertugas melakukan pengawasan dan memberikan nasihat kepada direksi dalam menjalankan pengurusan perseroan. ${ }^{16}$

Fungsi dewan komisaris adalah mencakup dua peran sebagai berikut : Mengawasi direksi perusahaan dalam mencapai kinerja dalam business plan dan memberikan nasehat kepada direksi mengenai penyimpangan pengelolaan usaha yang tidak sesuai dengan arah yang ingin dituju oleh perusahaan; dan Memantau penerapan dan efektivitas dari praktek GCG.

Lingkup tugas dan wewenang serta tanggung jawab anggota komisaris secara umum telah diatur dalam UUPT khususnya Pasal 94 sd Pasal 101.

Dewan Komisaris merupakan Majelis dan setiap Anggota Dewan Komisaris tidak dapat bertindak sendirisendiri, melainkan berdasarkan berdasarkan keputusan Dewan Komisaris. Yang dimaksud dengan "Dewan Komisaris" adalah organ perseroan yang bertugas melakukan pengawasan secara umum dan/atau khusus sesuai dengan Anggaran Dasar serta memberi nasihat kepada Direksi. Anggota Dewan Komisaris diangkat oleh RUPS. ${ }^{17}$

Keberadaan PT BUMD setelah berubah bentuk dari PD hanya akan eksis dan berkelanjutan tidak hanya didukung oleh regulasi yang jelas namun yang terpenting adalah penempatan orang-orang yang tepat (dalam hal ini adalah tentang SDM) pada organ perusahaan, khususnya pada direksi dan komisaris.

12. Turiman Fachturahman Nur; Op.cit.

13. Abdul Kadir Muhamad, 2002, Hukum Perusahaan Indonesia, Bandung, Citra Aditya Bakti, hlm. 68.

14. Turiman Fachturahman Nur, Op.cit.

15. Ibid.

16. Abdul Kadir Muhamad, Op.Cit.

17. Fred B.G. Tumbuan, Tugas dan Wewenang Organ PT Menurut UU Tentang PT, Newsletter, Hukum dan Perkembangannya, No. 70, September 2007. 


\section{Pentingnya Penerapan Prinsip Good Corporate Governance Pada Pengelolaan Perusahaan Daerah}

Istilah GCG semakin populer dan mendapatkan tempat di bidang hukum korporasi karena terwujud dalam dua keyakinan, yaitu : Pertama, GCG merupakan salah satu kunci sukses perusahaan untuk tumbuh dan menguntungkan dalam jangka panjang, sekaligus memenangkan persaingan bisnis global, terutama bagi perusahaan yang telah mampu berkembang sekaligus menjadi terbuka. Kedua, krisis ekonomi dunia, di kawasan Asia dan Amerika Latin yang diyakini muncul karena kegagalan penerapan GCG. $^{18}$

Penerapan prinsip-prinsip GCG dapat menciptakan suasana kondusif bagi kelancaran pengelolaan bisnis perusahaan, termasuk meningkatkan daya saing. GCG menjadi salah satu daya tarik investor dan para kreditor untuk mau meminjamkan dananya kepada perusahaan.

Good corporate governance memiliki nilai-nilai positif untuk menjaga konsistensi serta profesionalisme perusahaan dalam melakukan berbagai macam tindakan menuju kearah kinerja y.ang lebih baik. Hal ini didasarkan bahwa dalam GCG terdapat empat prinsip, yaitu pinsip kewajaran, keterbukaan informasi, dapat dipertanggungjawabkan dan pertanggungjawaban. ${ }^{19}$

Sebagian besar perusahaan yang tidak stabil, disebabkan oleh sikap dan cara pengelolaan yang tidak menerapkan nilainilai GCG secara tepat sehingga untuk menjaga agar perusahaan tetap stabil, maka semua kekuatan sumber daya perusahaan secara keseluruhan dan utuh harus mampu menjaga efektivitas, efisiensi dan produktivitas dari asset-liability-equity perusahaan, termasuk cash flow dan profit perusahaan dalam keseimbangan yang tepat dengan cara-cara pengelolaan yang patuh pada penerapan prinsip-prinsip $\mathrm{GCG}^{20}$

Peranan $G C G$ selain dapat membuat perusahaan menjadi kuat dan kokoh juga dapat melakukan semua kewajibankewajibannya kepada para pemegang saham maupun stake holders seperti gaji karyawan, biaya-biaya opersional rutin, biaya bunga pinjaman, baik biaya- biaya tetap maupun biaya-biaya tidak tetap lainnya, dengan melalui sistem dan kultur atau budaya korporasi yang terkait dengan etika dan moral serta nilai-nilai penerapan prinsip-prinsip $G C G .^{21}$

Di Indonesia, secara harfiah, governance kerap diterjemahkan sebagai "pengaturan." Adapun dalam konteks GCG, governance sering juga disebut "tata pamong". Selanjutnya GCG ini didefinisikan sebagai suatu pola hubungan, sistem, dan proses yang digunakan oleh organ perusahaan guna memberikan nilai tambah kepada pemegang saham secara berkesinambungan dalam jangka panjang, dengan tetap memperhatikan kepentingan stakeholder lainnya, berlandaskan peraturan perundangan dan norma yang berlaku. ${ }^{22}$

Pengertian GCG menurut Surat Keputusan Menteri Negara/Kepala Badan Penanaman Modal dan Pembinaan BUMN No. 23/M PM/BUMN/2000 tentang Pengembangan Praktik GCG dalam Perusahaan Perseroan (PERSERO), Good Corporate Governance adalah prinsip korporasi yang sehat yang perlu diterapkan dalam pengelolaan perusahaan yang dilaksanakan semata-mata demi menjaga kepentingan perusahaan dalam rangka mencapai maksud dan tujuan perusahaan.

Defenisi-definisi di atas dapat disimpulkan bahwa Good Corporate Governance merupakan : ${ }^{23}$

a. Suatu struktur yang mengatur pola

18. Dyah Permata Budi Asri, "Pelaksanaan Good Corporate Governance Dalam UU Nomor 40 Tahun 2007 Tentang PT', 19. tersedia di website http://janabadra.cic.id/ujb/00-2411-7401-pdf), diakses pada tanggal 25 Februari 2014.

20.Sutan Remy Sjahdeini, "Pengembangan Fungsi Pengawasan Menuju Good Corporate Governance pada Milenium baru", Makalah disajikan pada Seminar yang diselenggarakan Yayasan Pendidikan Internal Auditor (YPAI), Graha 21. Sucofindo, Jakarta pada Tanggal 29 September 1999, tidak diterbitkan.

21. Ibid.

22.Ahmad Rivai. 2006; “Analisis Pengaruh Implementasi Good Corporate Governance Terhadap Kinerja PT Kalbe Farma, Tbk." (Online), tersedia di website http://library.gunadarma.ac.id/index.ph

23. $\mathrm{p}$ ?appid=penulisan\&sub=detail\&np\&npm=20202080\&jenis=s1 fe), diakses pada tanggal 26 Februari 2014. (Online), tersedia di website http://re-searchengines.com/hsulistyanto3.html, diakses pada tanggal 15 Januari 2014. 
hubungan harmonis tentang peran dewan komisaris, Direksi, Pemegang Saham dan Para Stakeholder lainnya.

b. Suatu sistem pengecekan dan perimbangan kewenangan atas pengendalian perusahaan yang dapat membatasi munculnya dua peluang: pengelolaan yang salah dan penyalahgunaan aset perusahaan.

c. Suatu proses yang transparan atas penentuan tujuan perusahaan, pencapaian, berikut pengukuran kinerjanya.

Berbagai defenisi yang telah diuraikan dan terhadap perkembangan teori-teori korporasi jika dikaitkan dengan pentingnya good corporate governance ${ }^{24}$ maka dapat dilihat pada Tabel 1 .

Tabel 1. Perkembangan Teori Korporasi

dan Implikasinya Terhadap Good Corporate Governance

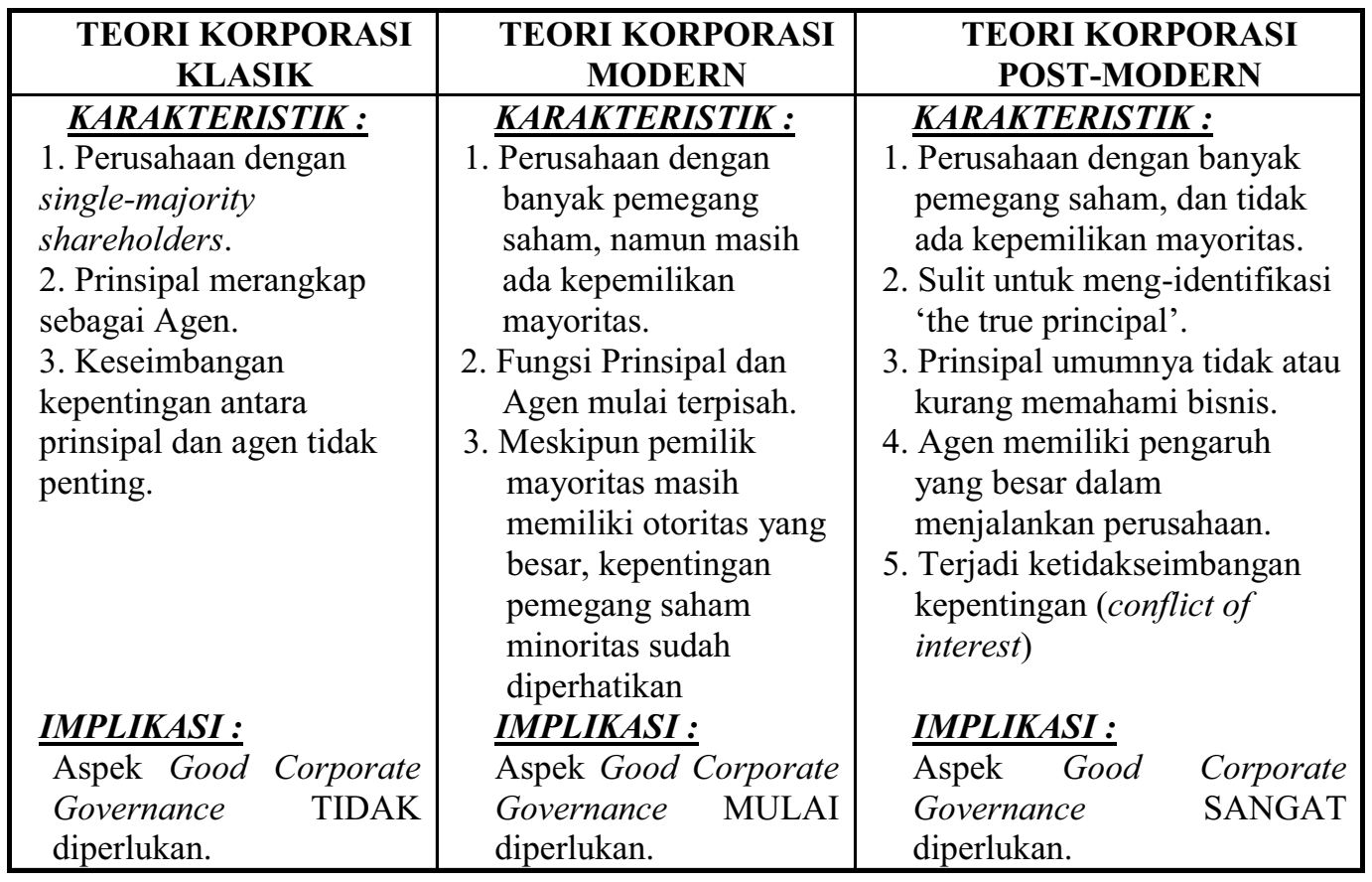

Undang-Undang Perseroan Terbatas mewajibkan setiap perusahaan yang berbentuk PT melakukan kegiatan usahanya dengan mengikuti prinsip tata kelola perusahaan yang baik sehingga perusahaan tersebut dapat dikategorikan sebagai perusahaan yang sehat (sebagaimana yang diatur dalam penjelasan Pasal 4 UU PT) . Badan Usaha Milik Daerah dalam hal ini Perusahaan Dearah Flobamor yang telah berubah bentuk menjadi PT Flobamor (berdasarkan Perda Nomor 13 tahun 2009 tentang Perubahan Bentuk Badan Hukum Perusahaan Daerah (PD) Flobamor menjadi
Perseroan Terbatas (PT), dalam pelaksanaan kegiatan korporasinya belum menggunakan prinsip Tata Kelola Perusahaan Yang Baik, hal ini ditandai dengan terus meruginya PT Flobamor, pertanggungjawaban keuangan yang tidak akurat, kurang berfungsinya komisaris sebagai pengawas perusahaan. Hal ini disebabkan juga oleh karena modal yang diperoleh PT Floamor berasal dari dana kekayaan daerah yang dipisahkan dari APBD yang diberikan oleh Pemerintah Daerah, sehingga walaupun perusahaan mengalami kerugian namun tetap mendapat penyertaan modal dari pemerintah, disamping itu

\footnotetext{
24.Jensen M.C. and Meckling, W.H, 1976, "Theory of the Firm: Managerial Behavior, Agency Cost and Ownership Structure", Journal of Financial Economics, Vol. 3, October 1976, pp. 305-360.
} 
masalah yang ada dalam PT Flobamor adalah penyertaan modal yang diberikan oleh pemerintah daerah tidak diberikan secara langsung sesuai dengan jumlah yang telah ditetapkan dalam perda, namun diberikan secara bertahap kepada manajemen bergantung kepada kehendak pemerintah sehingga perusahaan tidak dapat bekerja secara maksimal, selain itu keberadaan PT Flobamor pada awal dibentuknya adalah dalam rangka penyertaan modal pemerintah dalam pembangunan PT Semen Kupang, sehingga pemerintah tidak memberikan perhatian yang cukup dalam pengawasan dan evaluasi perusahaan. Selain persoalanpersoalan diatas PT Flobamor juga menghadapi sejumlah masalah korupsi yang dilakukan oleh manajemen perusahaan yang untuk sementara ini kasus-kasus korupsi tersebut sementara disidangkan di Pengadilan Negeri Klas I A Kupang khususnya dalam Peradilan Tipikor.

Undang-Undang Nomor 40 Tahun 2007 tentang Perseroan Terbatas menegaskan tentang prinsip-prinsip Good Corporate Governance atau prinsip tata kelola perusahaan yang baik dalam pengelolaan perusahaan, korporasi (termasuk perusahaan daerah yang berbentuk PT) yang baik harus mencerminkan prinsip-prinsip sebagai berikut:

a. Fairness (kewajaran)

Prinsip keadilan menjamin bahwa setiap keputusan dan kebijakan yang diambil adalah demi kepentingan seluruh pihak yang berkepetingan baik itu pelanggan, shareholders ataupun masyarakat luas. Prinsip keadilan ini tercermin dalam Pasal 53 ayat (2) bahwa : "Setiap saham dalam klasifikasi yang sama memberikan kepada pemegangnya hak yang sama

b. Transparansi (keterbukaan informasi) Yaitu keterbukaan, yang diwajibkan oleh undang-undang seperti misalnya mengumukan pendirian PT dalam Tambahan Berita Negara Republik Indonesia ataupun Surat Kabar. Serta keterbukaan yang dilakukan oleh perusahaan menyangkut masalah keterbukaan informasi ataupun dalam hal proses pengambilan keputusan maupun dalam mengungkapkan informasi mengenai perusahaan yang akurat, jelas dan tepat waktu baik kepada shareholders maupun stakeholder.

c. Akuntabilitas (dapat dipertanggungjawabkan)

Adanya keterbukaan informasi dalam bidang finansial, dalam hal ini ada dua pengendalian yang dilakukan oleh direksi dan komisaris. Direksi menjalankan operasional perusahaan, sedangkan komisaris melakukan pengawasan terhadap jalannya perusahaan oleh Direksi, termasuk pengawasan keuangan. Sehingga sudah sepatutnya dalam suatu perseroan, Komisaris Independent mutlak diperlukan kehadirannya. Sehingga adanya jaminan tersedianya mekanisme, peran dan tanggung jawab jajaran manajemen yang professional atas semua keputusan dan kebijakan yang diambil sehubungan dengan aktivitas operasional perseroan. PT Flobamor telah memilih direkur melalui mekanisme uji kelayakan dan kepatutan dan terhadap dewan komisaris dipilih dari orang-orang yang indepent dalam melakukan pengawasan terhadap perusahaan, namun keberadaan kedua organ (orang-orang yang telah dipilih untuk menjabat direktur dan komisaris) setelah berubah bentuk menjadi PT Flobamor harus diuji dengan melihat kinerja manajemen dalam RUPS.

d. Responsibility (pertanggung-jawaban) Pertanggungjawaban perseroan dilakukan dengan tidak merugikan kepentingan para stakeholder dan shareholders maupun anggota masyarakat secara luas. UndangUndang mewajibkan perseroan haruslah berpegang pada hukum yang berlaku. Berpegang pada hukum yang berlaku adalah yang berkaitan dengan masalah pajak, hubungan industrial, perlidungan lingkungan hidup, kesehatan dan keselamatan kerja, standar penggajian dan persaingan yang sehat. Sebelum berubah bentuk menjadi PT, salah satu contoh : jumlah karyawan pada 
perusahaan PD Flobamor adalah 33 orang dan dalam sistem penggajian karyawan (karyawan PD Flobamor bukan PNS) bergantung kepada profit atau keuntungan dari perusahaan walaupun memang diatas UMR Provinsi. Setalah berubah status badan usaha PT Flobamor akan memperbaiki sistem pertanggungjawabannya yaitu tentang sistem perpajakkan perusahaan, hubungan industrial antara direksi dan karyawan, perlidungan lingkungan hidup tempat perusahaan melakuan investasi, kesehatan dan keselamatan kerja karyawan, standar penggajian yang lebih baik dan persaingan yang sehat antara PT Flobamor dengan perusahaan lain sehingga dapat menjadi perusahaan yang sehat.

Namum pada akhirnya, dalam hal penerapan prinsip GCG harus disadari bahwa penerapan Tata Kelola Perusahaan yang baik hanya akan efektif dengan adanya asas kepatuhan dalam kegiatan bisnis sehari-hari, terlebih dahulu diterapkan oleh jajaran manajemen dan kemudian diikuti oleh segenap karyawan dan seterusnya melalui penerapan yang konsisten, tegas dan berkesinambungan dari seluruh pelaku bisnis.

Esensi corporate governance adalah peningkatan kinerja perusahaan melalui supervisi atau pemantauan kinerja manajemen dan adanya akuntabilitas manajemen terhadap shareholders dan pemangku kepentingan lainnya berdasarkan kerangka aturan dan peraturan yang berlaku. ${ }^{25}$

Seberapa jauh perusahaan memperhatikan prinsip-prinsip dasar GCG telah menjadi faktor penting dalam pengambilan keputusan investasi. Terutama sekali hubungan antara praktik corporate governance dengan karakter investasi saat ini. Suatu perusahaan yang ingin menuai manfaat dari pasar modal global dan jika ingin menarik modal jangka panjang maka penerapan GCG secara konsisten dan efektif akan mendukung ke arah itu. Bahkan jikapun perusahaan tidak bergantung pada sumber daya dan modal asing, penerapan prinsip dan praktik GCG akan dapat meningkatkan keyakinan investor domestik terhadap perusahaan.

\section{Simpulan}

Berdasarkan hasil kajian sebagaimana telah diuraikan maka kesimpulan yang dapat diambil adalah, pertama, dengan beralihnya status badan usaha PD menjadi PT, kepemilikan saham tidak lagi menjadi monopoli pemerintah daerah tetapi sudah diberi kesempatan kepada pihak ketiga untuk melakukan penyertaan modal (privatisasi BUMD). Pemegang saham bertanggung jawab hanya sebesar saham yang ditanam dalam perusahaan. Tentang tanggung jawab, hak dan kewajiban dari pemegang saham tunduk kepada peraturan perundangundangan yang berlaku (tunduk kepada UU Nomor 40 Tahun 2007 tentang Perseroan Terbatas). Direksi adalah organ perseroan yang berwenang dan bertanggung jawab penuh atas pengurusan perseroan untuk kepentingan perseroan, sesuai maksud dan tujuan perseroan serta mewakili perseroan baik di dalam maupun di luar pengadilan sesuai ketentuan Anggaran Dasar (AD) sehingga dalam menjalankan tugas dan tanggung jawabnya direksi perusahaan mampu membawa PT BUMD menjadi perusahaan perseroan yang sehat yang sesuai dengan prinsip tata kelola perusahan yang baik. Komisaris adalah organ perseroan yang bertugas melakukan pengawasan secara umum dan/atau khusus sesuai dengan Anggaran Dasar serta memberi nasihat kepada Direksi. Komisaris PT BUMD akan bekerja sesuai dengan tugas dan tanggungjawabnya sebagaimana yang diatur dalam peraturan perundang-undangan, dimana komisaris PT BUMD dipilih dari unsur-unsur yang mempunyai kredibilitas dan idependensi dalam melakukan pengawasan.

Kedua, Perubahan status badan usaha PD menjdi PT BUMD adalah mendukung penyelenggaraan prinsip good corporate governance atau prinsip tata kelola perusahaan yang baik. Prinsip GCG ini disadari oleh management PT BUMD NTT penting untuk dilaksanakan karena salah satu

\footnotetext{
25.Deni Darmawati, 2006, "Pengaruh Karakteristik Perusahaan dan Faktor Regulasi terhadap Kualitas Implementasi Corporate Governance”, Makalah disajikan pada Simposium Nasional Akuntansi IX, Padang 23-26 Agustus 2006.
} 
unsur yang membuat perusahaan menjadi sehat adalah diberlakukannya prinsip-prinsip tata kelola perusahaan yang baik. Prinsip GCG ditandai dengan adanya : prinsip kewajaran (fairness), yaitu perlakuan yang adil dan setara dalam pemenuhan hak-hak shareholders maupun stakeholders; prinsip keterbukaan informasi (tranparency), yaitu penyediaan informasi yang cukup, akurat dan tepat waktu kepada berbagai pihak yang berkaitan dengan perusahaan; prinsip dapat dipertanggungjawabkan (accuntability), yaitu adanya kejelasan fungsi, struktur, sistem dan sistem pertanggungjawaban organ perusahaan sehingga pengelolaan perusahaan terlaksana secara efektif; dan prinsip pertanggungjawaban (responsibility), yaitu kesesuaian didalam pengelolaan perusahaan terhadap prinsip korporasi yang sehat serta peraturan perundang-undangan yag berlaku.

\section{Daftar Pustaka}

B.G. Tumbuan Fred, "Tugas dan Wewenang Organ PT Menurut UU Tentang PT", $\mathrm{N}$ ew s le t t e r, H u k u d a n Perkembangannya, No. 70, September 2007.

Darmawati Deni, 2006 , "Pengaruh Karakteristik Perusahaan dan Faktor Regulasi terhadap Kualitas Implementasi Corporate Governance", Makalah disajikan pada Simposium Nasional Akuntansi IX, Padang 23-26 Agustus 2006.

Fachturahman Nur Turiman, 2009, "Terobosan Hukum Memajukan Badan Usaha Milik Daerah (BUMD) Dala Era Otonomi Daerah, Rajawali Garuda Pancasila", tersedia di website http://Rajawaligarudapancasila.blogsp ot.com/2011/04/Terobosan-hukummemajukan-badan-usaha.Html, diakses pada tanggal 26 April 2014.

Fuady Munir, 1994, "Potret Hukum Bisnis Kita Dewasa Ini", Surat kabar Bisnis Indonesia, 15 Oktober 1993, dalam : Hukum Bisnis Dalam Teori dan Praktek Bagian Kesatu, Bandung, Citra Aditya Bakti.

Kadir Muhamad Abdul, 2002, Hukum Perusahaan Indonesia, Bandung, Citra
Aditya Bakti

L.Tanya Bernard, Simanjuntak, Yoan N, Hage, Markus Y, 2006, Teori Hukum, Strategi Tertib Manusia Lintas Ruang dan Generasi, Surabaya, CV Kita.

M C Jensen, and W H,Meckling, "Theory of the Firm: Managerial Behavior, Agency Cost and Ownership Structure", Journal of Financial Economics, Vol. 3, October 1976, pp. 305-360.

Pazri Muhammad, "Implementasi Prinsip Good Governance Dalam Sistem Pengelolaan Keuangan Daerah di Indonesia" Badamai Law Journal, Vol. 1, Issues 2, September 2016.

Permata Budi Asri Dyah, "Pelaksanaan Good Corporate Governance Dalam UU Nomor 40 Tahun 2007 Tentang PT', t e r s e d i a d i w e b s i t e http://janabadra.cic.id/ujb/00-24117401-pdf), diakses pada tanggal 25 Februari 2014.

Remy Sjahdeini Sutan, "Pengembangan Fungsi Pengawasan Menuju Good Corporate Governance pada Milenium baru", Makalah disajikan pada Seminar yang diselenggarakan Yayasan Pendidikan Internal Auditor (YPAI), Graha Sucofindo, Jakarta pada Tanggal 29 September 1999, tidak diterbitkan.

Rivai Ahmad, 2006, Analisis Pengaruh Implementasi Good Corporate Governance Terhadap Kinerja PT Kalbe Farma, Tbk. (Online), tersedia di w $\quad$ e $\quad b \quad s \quad$ i $t \quad r$ http://library.gunadarma.ac.id/index.ph p?appid $=$ penulisan $\&$ sub $=$ detail $\& n p \& n$ $\mathrm{pm}=20202080 \&$ jenis $=\mathrm{s} 1 \mathrm{fe}$ ), diakses pada tanggal 26 February 2014.

Sulistyanto Sri dan Haris Wibisono, 2003, Good Corporate Governance: Berhasilkah Diterapkan di Indonesia? (Online), tersedia di website http://researchengines.com/hsulistyanto3.html, diakses pada tanggal 15 Januari 2014.

Westra I Ketut, 2012, "Kedudukan Hukum Perusahaan Daerah Sebagai Badan Usaha Milik Daerah untuk Meningkatkan Pendapatan Asli Daerah", Disertasi, tersedia di website http://prasetya.ub.ac.id/berita/disertasi -I-Ketut-Westra, diakses pada tanggal 
06 Mei 2014.

"Media Informasi Otonomi Daerah Indonesia; Tujuan Otonomi Daerah", t e r s e d i a d i w e b s i e http://otonomidaerah.com/tujuanotonomi-daerah/, diakses pada tanggal 06 April 2014.

"PD Flobamor, Ibarat Membuang Garam Ke laut", Pos Kupang, edisi 21 Oktober 2008, hlm 1, tersedia di website http://www.pos-kupang.com, diakses pada tanggal 11 Januari 2010.

"Neraca Keuangan PT Flobamor Merah (Tak Boleh Ada Penyertaan Modal Pemerintah)", Pos Kupang, edisi 19 Desember 2013, hlm 1, tersedia di website http://www.pos-kupang.com, diakses pada tanggal 20 Desember 2013.

Undang-Undang Nomor 1 Tahun 1995 jo Undang-Undang Nomor 40 Tahun 2007 Tentang Perseroan Terbatas.

Peraturan Daerah Provinsi Nusa Tenggara Timur Nomor 13 Tahun 2009 tentang Perubahan Bentuk Badan Hukum PD Flobamor menjadi PT Flobamor. 